\title{
Antioxidant and Anticancer Efficacies of Anethum graveolens against Human Breast Carcinoma Cells through Oxidative Stress and Caspase Dependency
}

\author{
Mai M. Al-Oqail and Nida N. Farshori $(\mathbb{D}$ \\ Department of Pharmacognosy, College of Pharmacy, King Saud University, P.O. Box 22452, Riyadh 11495, Saudi Arabia \\ Correspondence should be addressed to Nida N. Farshori; nidachem@gmail.com
}

Received 18 January 2021; Accepted 24 April 2021; Published 4 May 2021

Academic Editor: Yujiang Fang

Copyright (C) 2021 Mai M. Al-Oqail and Nida N. Farshori. This is an open access article distributed under the Creative Commons Attribution License, which permits unrestricted use, distribution, and reproduction in any medium, provided the original work is properly cited.

\begin{abstract}
Anethum graveolens, belonging to the family Apiaceae, has been extensively used for medicinal and therapeutic purposes since long. Plants encompass rich number of effective constituents with less toxicity. Thus, nowadays, the attempts are being made to search plant constituents that can prevent and reverse the chronic diseases, such as cancer. In this study, an in vitro antioxidant and anticancer efficacies of Anethum graveolens (AG-ME) were studied on human breast (MCF-7), lung (A-549), and cervical (HeLa) carcinoma cell lines. The antioxidant efficacies of AG-ME were evaluated by total antioxidant, DPPH radical scavenging, $\mathrm{H}_{2} \mathrm{O}_{2}$ scavenging, and ferrous reducing antioxidant assays. Further, the anticancer potential of AG-ME was also determined against different cancer cell lines. The AG-ME exhibited strong antioxidant activities as observed by antioxidant assays. AG-ME also showed a dose-dependent anticancer/cytotoxic potential against MCF-7, A-549, and HeLa cell lines. The AG-ME-induced reduction in GSH and increase in SOD activities indicates the role of oxidative stress in AG-ME-induced MCF-7 cell death. The results also exhibited that AG-ME triggered ROS production and significantly reduced MMP level. Moreover, a dose-dependent increase in caspase-3 and caspase- 9 activities suggests that the AG-ME-induced MCF-7 cell death is caspase-dependent. Together, the present study provides reasoning and reassurance for the uses of A. graveleons for medical purposes as an antioxidant and anticancer agent. Additional investigations are required to examine biological and anticancer activities under an in vivo system to discover a possible beneficial use of AG-ME against diseases.
\end{abstract}

\section{Introduction}

Free radicals and ROS are produced by physiological and biochemical processes in the human body [1]. A number of chemically reactive radicals, i.e., superoxide, hydroxyl radicals, and $\mathrm{H}_{2} \mathrm{O}_{2}$, are derived from oxygen during ROS generation [2]. It is well documented that overproduction of such free radicals can cause serious damage to biomolecules such as DNA, RNA, proteins, and lipids, which leads to pathogenic conditions to human [2]. ROS play the most important character in the pathogenesis of diverse physiological conditions, such as cellular damage, neurodegenerative, diabetes, hepatic, and cardiovascular diseases [3]. Endogenous antioxidant enzymes, e.g., glutathione peroxidase, superoxide dismutase, and catalase are accomplished of neutralizing free radicals, and hence, sustaining optimum cellular activities [4]. Nonetheless, under high ROS production and oxidative stress, these endogenous antioxidant enzymes may not be adequate to maintain optimum cellular activities. Thus, the dietary antioxidants may be essential. Natural products or plants have always been used to treat and cure various diseases since ages $[5,6]$. Plants produced various secondary metabolites, for example alkaloids, terpenoids, flavonoids, and vitamins, that take part in the neutralization of free radicals and delay chronic ailments caused by ROS and oxidative stress [7-9]. Natural antioxidants from plant materials play a vigorous part in the production against the action of free radicals $[10,11]$. Numerous studies have shown that consumption of plant seeds and leaves with strong antioxidant potential and are capable to lower the causation of different 
chronic diseases like cancer [12-14]. Anethum graveolens (family: Apiaceae) is known for medicinal and therapeutic purposes since long in the conventional system of medicine [15]. A. graveolens has been described for its biological potential and pharmacological potential, e.g., antioxidant [16], anti-inflammatory [17], antidiabetic [18], antimicrobial [19], and anticancer [20] activities. Ethanolic and acetonic extracts of $A$. graveolens flowers and leaf $[21,22]$ and essential oil of $A$. graveolens [16] have been shown to possess high antioxidant activities. Cancer is the abnormal growth of cells which forms a tumor. These cells are different than normal cells and are not accountable for normal growth controlling mechanisms [23]. The cytotoxic/antiproliferative potential of plants and plant-derived components can be measured by different cytotoxic endpoints, such as MTT, neutral red uptake, and cellular morphological analyses, using various cancer cell lines [24-26]. The available treatment for cancer is chemotherapy and radiotherapy, but the main disadvantage of current drugs is their side effects [25]. Plants encompass rich number of effective constituents with less toxicity [27]. Thus, nowadays, the attempts are being made to search an anticancer agent from plant origin which can prevent and reverse the development of cancer [28, 29]. Hence, this study was aimed at investigating the antioxidant and anticancer efficacies of $A$. graveolens (AG-ME) against different human cancer cells (MCF-7, A-549, and HeLa).

\section{Materials and Methods}

2.1. Chemicals. All chemicals used were obtained from Sigma Aldrich. Cell culture medium, trypsin, and antibiotic solution were purchased from Invitrogen. Plastic wares and consumables were obtained from Nunc, Denmark. All the reagents and solvents used were of analytical grade.

2.2. Sample Collection. A. graveolens seeds were purchased from Riyadh, Saudi Arabia. A taxonomist in the Botany Department, KSU, has identified the seeds, and a voucher specimen number has been submitted in the herbarium.

2.3. Preparation of Extract. The A. graveolens seeds were screened manually. Seeds were ground to a coarse powder. About $500 \mathrm{~g}$ of grounded seeds were soaked in 1.5-liter methanol for 7 days with regular agitation. The extract was filtered using Whatman \#1 filter paper and funnel. The filtrate was then concentrated to dryness in a rotary evaporator at $40^{\circ} \mathrm{C}$ under reduced pressure. The obtained methanolic extract of A. graveolens seeds, named as AG-ME, was stored at $4^{\circ} \mathrm{C}$ for further use.

\subsection{In Vitro Antioxidant Assays}

2.4.1. Total Antioxidant Power. The total antioxidant power of AG-ME was measured using the phosphomolybdate assay following the method reported [30]. In brief, $500 \mu \mathrm{l}$ of seed extracts $(50-1000 \mu \mathrm{g} / \mathrm{ml})$ was added to $3 \mathrm{ml}$ of reaction mixture $(0.6 \mathrm{M}$ sulphuric acid, $28 \mathrm{mM}$ sodium phosphate, and $1 \%$ ammonium molybdate). The mixer was then incubated at $95^{\circ} \mathrm{C}$ for $10 \mathrm{~min}$ to complete the reaction. After cooling, the reaction mixer was read at $695 \mathrm{~nm}$. The percent antioxi- dant power was calculated by the formula: $\left[\left(A_{0}-A_{1}\right) / A_{0}\right] \times$ 100 , where $A_{0}$ is the control O.D. and $A_{1}$ is the extract O.D.

2.4.2. 2,2-Diphenyl-1-picrylhydrazyl (DPPH) Assay. The DPPH scavenging activity of AG-ME was performed using [31] method with slight modifications. Briefly, $0.3 \mathrm{mM}$ of $\mathrm{DPPH}$ solution was prepared in alcohol and extract concentrations in DMSO. Then, designated well of 96-well plate was filled with $50 \mu \mathrm{l}$ of each concentrations of extracts and $50 \mu \mathrm{l}$ of DPPH solution. Following $30 \mathrm{~min}$ incubation, absorbance of the plate was read at $515 \mathrm{~nm}$. Ascorbic acid was used as the standard. The \% radical scavenging activity was determined by the formula: 100 - (sample reaction O.D./control reaction O.D.) $\times 100$.

2.4.3. Hydrogen Peroxide $\left(\mathrm{H}_{2} \mathrm{O}_{2}\right)$ Scavenging Assay. The $\mathrm{H}_{2} \mathrm{O}_{2}$ scavenging efficacy of AG-ME was performed by the $\mathrm{H}_{2} \mathrm{O}_{2}$ method as previously described [32]. In brief, extract solution $(50-1000 \mu \mathrm{g} / \mathrm{ml} ; 2 \mathrm{ml})$ was mixed with $4 \mathrm{ml}$ of $20 \mathrm{mM} \mathrm{H}_{2} \mathrm{O}_{2}$ solution in phosphate buffer $(\mathrm{pH}=7.4)$. Following $10 \mathrm{~min}$ incubation, the absorbance was measured at $230 \mathrm{~nm}$ wavelength. The scavenging activity of $\mathrm{H}_{2} \mathrm{O}_{2}$ was calculated using the following formula:

$$
\% \mathrm{H}_{2} \mathrm{O}_{2} \text { scavenging }=\left[\frac{A_{0}-A_{1}}{A_{0}}\right] \times 100 \text {, }
$$

where $A_{0}$ is the O.D. of control and $A_{1}$ is the O.D. of the extract.

2.4.4. Ferric Reducing Antioxidative Capacity. The ferric reducing capacity, which imitate AG-ME antioxidant efficacy, was estimated by $\mathrm{Fe}^{+3}$ to $\mathrm{Fe}^{+2}$ method [33]. In brief, $200 \mu \mathrm{l}$ of each concentrations of AG-ME was mixed with $2.5 \mathrm{ml}$ of $0.2 \mathrm{M}$ of sodium phosphate buffer and potassium ferricyanide solution $(1 \% w / v)$. Then, the solution was mixed by vertex and incubated for $20 \mathrm{~min}$ at $50^{\circ} \mathrm{C}$. Further, $2.5 \mathrm{ml}$ of trichloroacetic acid $(10 \% w / v)$ was added in the mixer. After centrifugation at $3000 \mathrm{rpm}$, a supernatant $(2.5 \mathrm{ml})$ was added with equal volume of deionized water and $0.5 \mathrm{ml}$ ferric chloride $(0.1 \% \mathrm{w} / \mathrm{v})$. The developed color was read at $700 \mathrm{~nm}$.

\subsection{In Vitro Anticancer Activity Assays}

2.5.1. Cell Culture Maintenance. MCF-7, A-549, and HeLa cell lines obtained from ATCC were cultured in Dulbecco's modified eagle's medium added with FBS (10\%) and antibiotic (1\%). All cell lines were maintained at $37^{\circ} \mathrm{C}$ in a $\mathrm{CO}_{2}$ incubator $\left(5 \% \mathrm{CO}_{2}\right)$.

2.5.2. Anticancer Activity (MTT Assay). The anticancer potential AG-ME was examined against MCF-7, A-549, and HeLa cells using 3-(4,5-dimethylthiozol-2-yl)-2,5-diphenyltetrazolium bromide salt, MTT assay [34]. The dried extract (AG-ME) was firstly dissolved in DMSO then diluted in a cell culture medium to reach the final concentrations of $10-1000 \mu \mathrm{g} / \mathrm{ml}$. The final concentration of the DMSO solvent used for cytotoxicity assessments was not more than $0.04 \%$ in culture medium. In brief, MCF-7, A-549, and HeLa cells were allowed to grow in 96-well plates $\left(1 \times 10^{4}\right.$ cells/well $)$ for 
overnight. The cells were then exposed to $10-1000 \mu \mathrm{g} / \mathrm{ml}$ concentrations of AG-ME for $24 \mathrm{~h}$. After incubation, $10 \mu \mathrm{l}$ MTT solution $(5 \mathrm{mg} / \mathrm{ml})$ was added in wells and incubated for $4 \mathrm{~h}$. The developed formazan crystals were dissolved in $200 \mu \mathrm{l} \mathrm{DMSO}$, and absorbance was read at $550 \mathrm{~nm}$.

2.5.3. Anticancer Activity (NRU) Assay. The anticancer efficacy of AG-ME was also assessed by NRU assay using the method as described previously [35]. Briefly, MCF-7, A549 , and HeLa cells were plated in a 96-well and were allowed to grow overnight. Afterwards, cells were treated to 10$1000 \mu \mathrm{g} / \mathrm{ml} \mathrm{AG-ME}$ for $24 \mathrm{~h}$. Following treatment, the cell culture medium was aspirated and replaced with medium containing $50 \mu \mathrm{g} / \mathrm{ml}$ neutral red dye. Following $3 \mathrm{~h}$ incubation, the dye was extracted using destaining solution $(50 \%$ ethanol, $49 \%$ water, and $1 \%$ acetic acid) and the plate was read at $550 \mathrm{~nm}$.

Considering $100 \%$ cell viability in control sets, viability of treated groups was calculated using the following formula:

$$
\% \text { cell viability }=\frac{\text { treated group }(\text { mean O.D. })}{\text { control group }(\text { mean O.D. })} \times 100 \text {. }
$$

2.5.4. Morphological Change Assessment. MCF-7, A-549, and HeLa cells were plated in 24-wells and were allowed to grow for overnight in a $\mathrm{CO}_{2}$ incubator. Thereafter, cells were treated for $24 \mathrm{~h}$ with $10-1000 \mu \mathrm{g} / \mathrm{ml}$ of AG-ME for $24 \mathrm{~h}$. The morphological changes were analyzed under light microscope at $20 \mathrm{x}$ magnification power.

2.5.5. SOD and GSH Activities. Role of oxidative stress in the cell death induced by AG-ME was assessed using commercially purchased kits (Cayman Chemicals) for glutathione (GSH) and superoxide dismutase (SOD) assays. Briefly, MCF-7 cells were seeded in 6-well culture plates and incubated for overnight. After exposing the cells at 250$1000 \mu \mathrm{g} / \mathrm{ml}$ of $\mathrm{AG}-\mathrm{ME}$, the cells were harvested and homogenate was prepared by sonication. Following the centrifugation, the supernatant of the control and exposed cells were collected and assay was done as per the protocol given with kits.

2.6. Quantitative and Qualitative ROS Assays. For measuring the quantitative and qualitative ROS generation, MCF-7 cells were treated with $250-1000 \mu \mathrm{g} / \mathrm{ml}$ of AG-ME. Subsequently, cells were incubated in DCF-DA fluorescent dye for $1 \mathrm{~h}$ in dark. Then, the fluorescence strength of qualitative DCFDA probe was visualized under a fluorescence microscope and quantitative intensity of the fluorescence was obtained by using a fluorescence microplate reader at 485 and $528 \mathrm{~nm}$ excitation and emission, respectively.

2.7. MMP Measurement. Loss of MMP in MCF-7 cells exposed to AG-ME was evaluated by using the Rh-123 fluorescent dye. In brief, MCF-7 cells were exposed to AG-ME at $250-1000 \mu \mathrm{g} / \mathrm{ml}$ for $24 \mathrm{~h}$. Then, cells were incubated with $\mathrm{Rh}-123$ dye $(10 \mu \mathrm{g} / \mathrm{ml})$. Afterwards, fluorescence intensity was observed as previously described [35], using a fluorescence microscope and measuring the plate using fluorescence microplate reader.
2.8. Measurement of Caspase-3 and Caspase-9 Activities. For the assessment of caspase activation, MCF-7 cells were treated with $250-1000 \mu \mathrm{g} / \mathrm{mL}$ of AG-ME. The activities of caspase- 3 and caspase- 9 were measured by using caspase colorimetric assay kits according to the manufacturer's recommended protocol (BioVision Inc., USA). The changes in caspase- 3 and caspase- 9 activities were determined by comparing the results with untreated control sets.

2.9. Statistical Analysis. The assay was performed in triplicates $(n=3)$ and were repeated in three independent experiments. ANOVA was used for statistical analysis, and values with $p<0.05$ were considered statistically significant.

\section{Results}

3.1. Total Antioxidant Power. The results of total antioxidant efficacy of $A$. graveolens seed extract (AG-ME) at different concentrations are shown in Figure 1(a). Since, the phosphomolybdate method is quantitative; therefore, the total AG$\mathrm{ME}$ antioxidant power is presented corresponding to ascorbic acid. AG-ME showed a concentration-dependent antioxidant activity at $50-1000 \mu \mathrm{g} / \mathrm{ml}$. At $100 \mu \mathrm{g} / \mathrm{ml}$, the antioxidant efficacy of AG-ME was $15.1 \%$, while at 250, 500, and $1000 \mu \mathrm{g} / \mathrm{ml}$, the antioxidant capacity of AG-ME was $36.3 \%$, $58.6 \%$, and $85.6 \%$, respectively. The $\mathrm{IC}_{50}$ value $(344.3 \mu \mathrm{g} / \mathrm{ml})$ of AG-ME showed considerable antioxidant capacity compared to ascorbic acid $(247.0 \mu \mathrm{g} / \mathrm{ml})$ (Table 1$)$.

3.2. DPPH Assay. DPPH results of AG-ME are given in Figure 1(b). The scavenging efficacy of DPPH radical was observed in a concentration-dependent way. The percent inhibition was found to be $25.45 \%, 41.82 \%, 55.40 \%$, $70.56 \%$, and $81.16 \%$ at $50,100,250,500$, and $1000 \mu \mathrm{g} / \mathrm{ml}$, respectively, for AG-ME. The percent DPPH radical inhibition by ascorbic acid was observed as $30.56 \%, 52.36 \%$, $64.37 \%, 84.63 \%$, and $95.40 \%$ at $50,100,250,500$, and $1000 \mu \mathrm{g} / \mathrm{ml}$, respectively. The AG-ME exhibited lower scavenging activity than ascorbic acid (Figure 1(b)). The $\mathrm{IC}_{50}$ of AG-ME was $225 \mu \mathrm{g} / \mathrm{ml}$, while ascorbic acid was $95 \mu \mathrm{g} / \mathrm{ml}$ (Table 1).

3.3. Hydrogen Peroxide Scavenging Activity. The results of scavenging potential of AG-ME on hydrogen peroxide are shown in Figure 2(a). As shown in the figure, a concentration-dependent $(50-1000 \mu \mathrm{g} / \mathrm{ml})$ strong hydrogen peroxide scavenging activity of AG-ME was observed. At the concentration of $500 \mu \mathrm{g} / \mathrm{ml}$, the $\mathrm{H}_{2} \mathrm{O}_{2}$ scavenging activity of AG-ME was 78.65\%; however, at the same concentration, ascorbic acid was $82.43 \%$. The $\mathrm{H}_{2} \mathrm{O}_{2}$ scavenging activity of AG-ME closely resembled to the ascorbic acid. The $\mathrm{IC}_{50}$ of AG-ME and ascorbic acid were $126.3 \mu \mathrm{g} / \mathrm{ml}$ and $100.5 \mu \mathrm{g} / \mathrm{ml}$, respectively (Table 1 ).

3.4. Ferric Reducing Antioxidative Capacity. This is a colorimetric method which is based on the reduction of ferric complex to ferrous colored form in the existence of antioxidant. The results of this assay are presented in Figure 2(b). As shown in the figure, a concentration-dependent increase in the reducing power of AG-ME and ascorbic acid was 


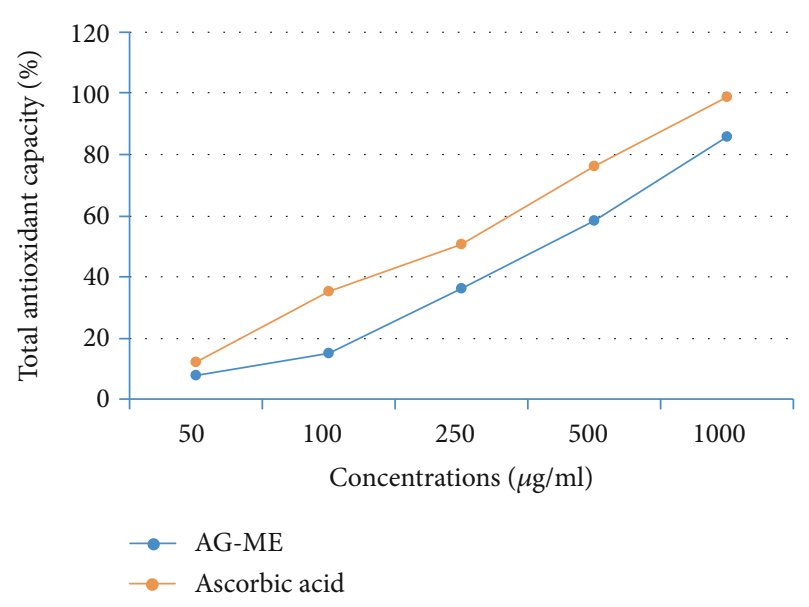

(a)

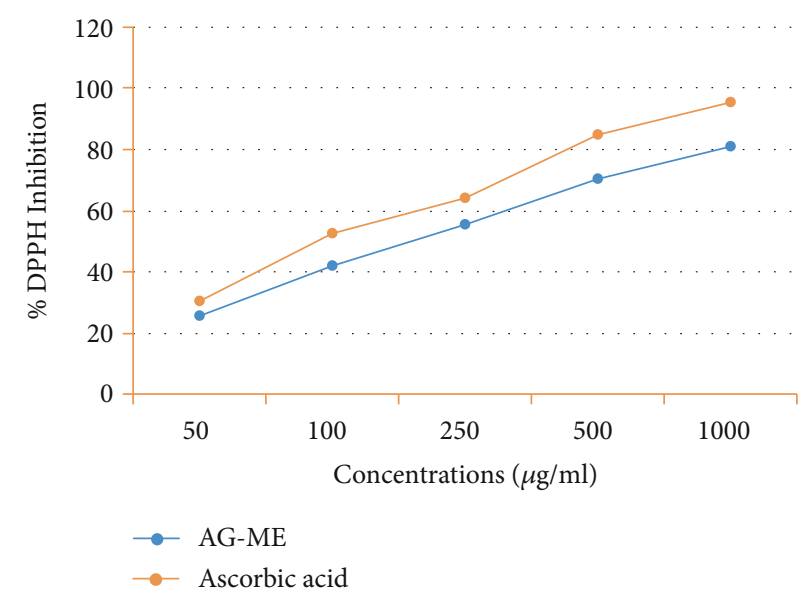

(b)

Figure 1: In vitro antioxidant activities of Anethum graveolens seed extract (AG-ME) at 50-1000 $\mu \mathrm{g} / \mathrm{ml}$ concentrations. (a) Total antioxidant capacity. (b) DPPH radical scavenging activity.

TABLE 1: Inhibitory concentration $\left(\mathrm{IC}_{50}\right)$ values of antioxidant activities of AG-ME and standard obtained by different assays.

\begin{tabular}{lcc}
\hline \multirow{2}{*}{ Assays } & \multicolumn{2}{c}{$\mathrm{IC}_{50}(\mu \mathrm{g} / \mathrm{ml})$} \\
& $\mathrm{AG}-\mathrm{ME}$ & Ascorbic acid \\
\hline Total antioxidant capacity & 225.0 & 95.0 \\
DPPH radical scavenging activity & 344.3 & 247.0 \\
Hydrogen peroxide scavenging activity & 126.3 & 100.5 \\
\hline
\end{tabular}

observed. The increased absorbance of the reaction solution indicates the increased reducing power of extract and standard. The maximum absorbance of the AG-ME was 1.387, compared to 2.231 for ascorbic acid at $1000 \mu \mathrm{g} / \mathrm{ml}$. At the dosage of $50-1000 \mu \mathrm{g} / \mathrm{ml}$ of AG-ME, ascorbic acid showed reducing values of $0.143-0.997$ and $0.231-1.534$, respectively (Figure 2(b)).

3.5. Anticancer Activity (MTT Assay). MTT assay was conducted to assess the anticancer effects of AG-ME at different concentrations on MCF-7, A-549, and HeLa cell lines. As observed by MTT assay and depicted in Figure 3, the AGME decreased the MCF-7, A-549, and HeLa cell viability in a concentration-dependent way. The MCF-7 cell viability was found to be $10 \%, 19 \%, 31 \%, 48 \%, 69 \%$, and $81 \%$ at $1000,500,250,100,50$, and $25 \mu \mathrm{g} / \mathrm{ml}$ of AG-ME, respectively (Figure 3(a)). The A-549 cell viability was found to be $21 \%$, $30 \%, 46 \%, 59 \%, 75 \%$, and $89 \%$ at $1000,500,250,100,50$, and $25 \mu \mathrm{g} / \mathrm{ml}$ of AG-ME, respectively, (Figure 3(b)); however, in HeLa cells, the viability was recorded as $29 \%, 42 \%$, $55 \%, 68 \%, 80 \%$, and $95 \%$ at 1000, 500, 250, 100, 50, and $25 \mu \mathrm{g} / \mathrm{ml}$ of AG-ME, respectively, (Figure 3(c)). The cell viability of MCF-7 was decreased by AG-ME even at lower concentrations, i.e., 25 and $50 \mu \mathrm{g} / \mathrm{ml}$. The MCF-7 cells were shown to be more sensitive towards AG-ME followed by A-549 and HeLa cells. The $\mathrm{IC}_{50}$ values obtained for MCF-7, A-549, and HeLa cells were $104 \mu \mathrm{g} / \mathrm{ml}, 122 \mu \mathrm{g} / \mathrm{ml}$, and $156 \mu \mathrm{g} / \mathrm{ml}$, respectively by MTT assay (Table 2).
3.6. Anticancer Activity (NRU Assay). The anticancer efficacy of increasing concentrations of AG-ME on MCF-7, A-549, and HeLa cells was also evaluated by NRU assay. The results are presented in Figure 4. As shown in the figure, the percent viability of MCF-7 cells was recorded as $14 \%, 23 \%, 36 \%, 54 \%$, $75 \%$, and $85 \%$ at $1000,500,250,100,50$, and $25 \mu \mathrm{g} / \mathrm{ml}$ of AGME, respectively (Figure 4(a)). The viability of A-549 cells was decreased from $89 \%$ to $21 \%$ between 25 and $1000 \mu \mathrm{g} / \mathrm{ml}$ of AG-ME (Figure 4(b)); however, the viability of HeLa cells was decreased from $95 \%$ to $29 \%$ between 25 and $1000 \mu \mathrm{g} / \mathrm{ml}$ of AG-ME (Figure 4(c)). Similar to MTT assay, MCF-7 cells were more sensitive towards AG-ME followed by A-549 and HeLa cells by NRU assay. The $\mathrm{IC}_{50}$ values by NRU assay were $109 \mu \mathrm{g} / \mathrm{ml}, 250 \mu \mathrm{g} / \mathrm{ml}$, and $312 \mu \mathrm{g} / \mathrm{ml}$ for MCF-7, A-549, and HeLa cells, respectively (Table 2 ).

3.7. Morphological Change Assessment. The changes in cellular morphology of MCF-7, A-549, and HeLa cells are shown in Figure 5. As shown in the figure, obvious morphological changes were observed at $24 \mathrm{~h}$ treatment with AG-ME at $1000 \mu \mathrm{g} / \mathrm{ml}$. Compared to untreated control, the MCF-7, A549, and HeLa cells exposed to AG-ME at $1000 \mu \mathrm{g} / \mathrm{ml}$ lost their original shape, become less in number, rounded, and shrunken with apoptotic bodies (Figure 5).

3.8. SOD and GSH Activities. To study the oxidative stressmediated cytotoxicity of AG-ME in MCF-7 cells, SOD and GSH activities were measured by exposing the cells with various concentrations of AG-ME $(250,500$, and $1000 \mu \mathrm{g} / \mathrm{mL})$ for $24 \mathrm{~h}$. MCF-7 cells treated with AG-ME exhibited a concentration-dependent increase in SOD and a reduction in GSH activities. The reduction in the GSH activity was observed as $14 \%, 39 \%$, and $60 \%$ at 250,500 , and $1000 \mu \mathrm{g} / \mathrm{mL}$, respectively, (Figure 6(a)). However, MCF-7 cells treated with 250,500 , and $1000 \mu \mathrm{g} / \mathrm{mL}$ of AG-ME showed an increase of $10 \%, 28 \%$, and $42 \%$, respectively, in SOD activity (Figure 6(b)). 


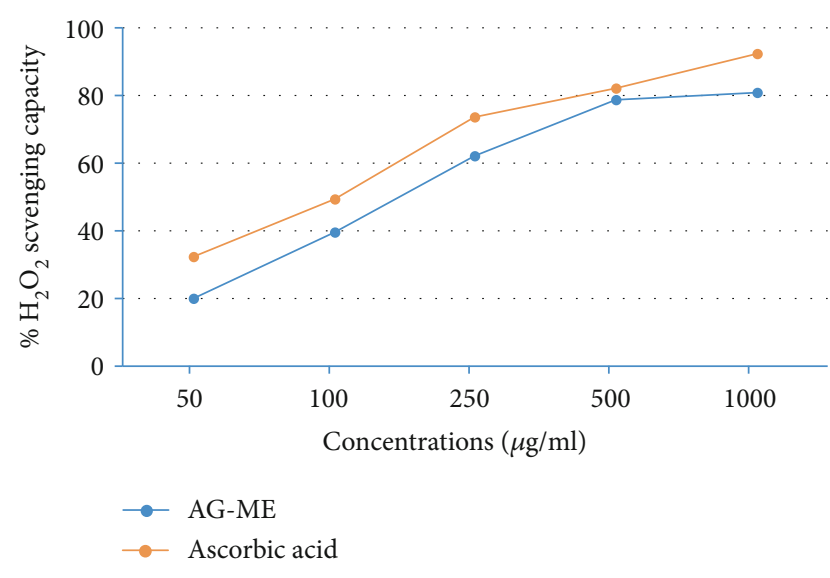

(a)

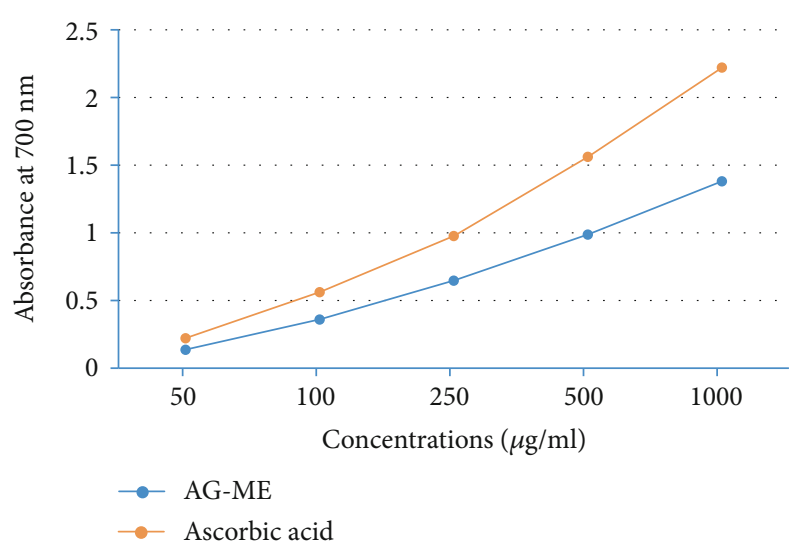

(b)

FIGURE 2: In vitro antioxidant activities of Anethum graveolens seed extract (AG-ME) at 50-1000 $\mu \mathrm{g} / \mathrm{ml}$ concentrations. (a) $\mathrm{H}_{2} \mathrm{O}_{2}$ scavenging capacity. (b) Ferric reducing antioxidative capacity.

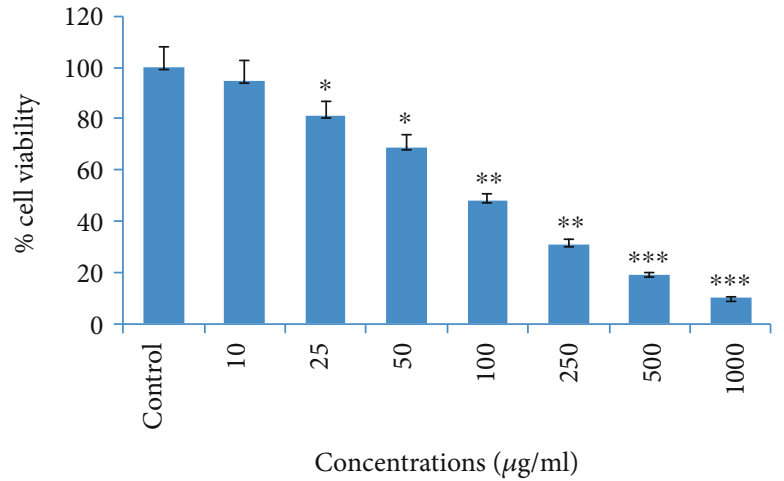

(a)

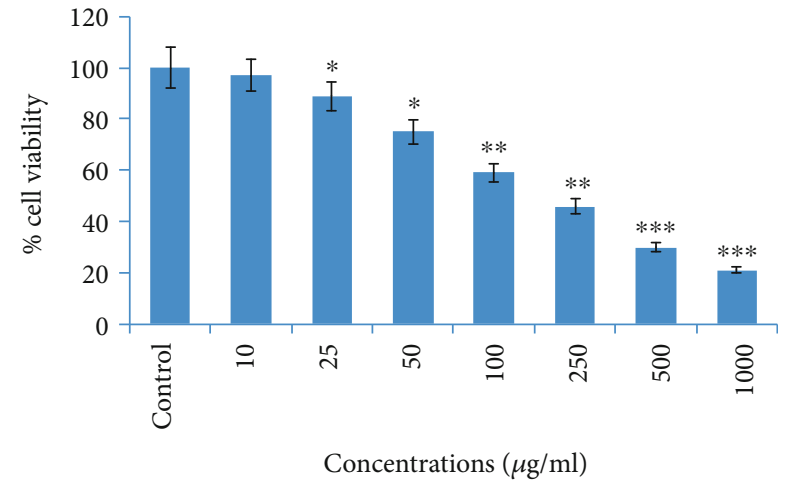

(b)

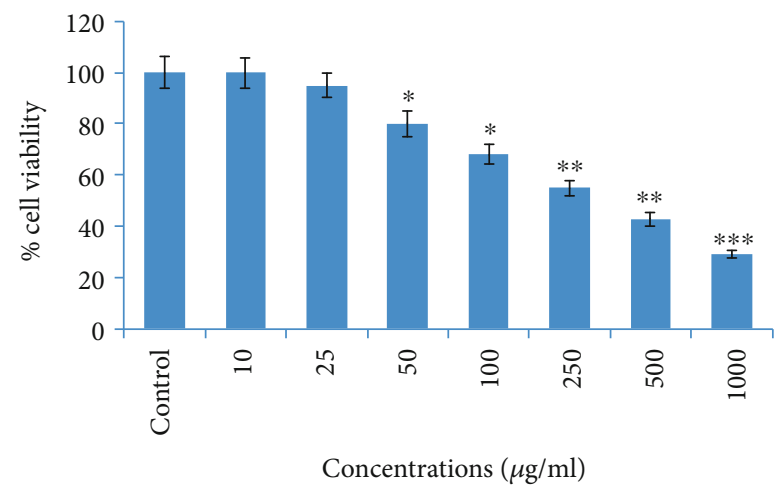

(c)

Figure 3: Cytotoxic potential of AG-ME against three different cancer cell lines exposed to 10-1000 $\mu \mathrm{g} / \mathrm{ml}$ measured by MTT assay: (a) MCF7 cells, (b) A-549 cells, and (c) HeLa cells. The results are presented as the mean \pm S.D. of three different experiments. ${ }^{*} p<0.05,{ }^{* *} p<0.01$, and ${ }^{* * *} p<0.001$ vs. the control.

3.9. Quantitative and Qualitative ROS Generation. DCF-DA dye was used to evaluate whether AG-ME could induce ROS generation in MCF-7 cells. The fluorescence microscopic images of qualitative ROS production and quantitative analysis have positively indicated that the treatment of AG-ME at 250,500 , and $1000 \mu \mathrm{g} / \mathrm{mL}$ significantly increases the cellular
ROS production with the increasing doses of AG-ME (Figures 6(c) and 6(d)).

3.10. MMP Measurement. To examine the decrease of MMP induced by AG-ME, the MCF-7 cells were treated at various concentrations of AG-ME. The decrease of MMP is one of 
TABLE 2: Inhibitory concentration $\left(\mathrm{IC}_{50}\right)$ of AG-ME on MCF-7, A-549, and HeLa cell lines measured by MTT assay and NRU assay.

\begin{tabular}{lcc}
\hline Cell lines & MTT assay & $\mathrm{IC}_{50}(\mu \mathrm{g} / \mathrm{ml})$ \\
\hline MCF-7 & 104 & NRU assay \\
A-549 & 122 & 109 \\
HeLa & 156 & 250 \\
\hline
\end{tabular}

the early biochemical markers of apoptosis progression. To determine the depletion in MMP level, we used Rh-123 dye which indicates potential-dependent accretion in the mitochondria. As depicted in Figures 7(a) and 7(b), a significant dose-dependent decline of MMP occurred in MCF-7 cells exposed to AG-ME. The results exhibited a $14 \%, 32 \%$, and $49 \%$ of loss in MMP at 250, 500, and $1000 \mu \mathrm{g} / \mathrm{mL}$, respectively.

\subsection{Measurements of Caspase-3 and Caspase-9 Activities.} In order to assess the involvement of caspases in AGME-induced MCF-7 cell death, the activities of caspase-3 and caspase-9 enzymes were investigated. As given in Figures 7(c) and 7(d), the AG-ME exposure caused caspase3 and caspase- 9 activation in a concentration-dependent manner $(p<0.01)$. The results showed that MCF-7 cells exposed to AG-ME increased the caspase-3 activity by 1.3-, 1.7-, and 2.1-fold (Figure 7(c)) and caspase-9 activity 1.2-, 1.6-, and 1.9-fold (Figure 7(d)) at 250, 500, and $1000 \mathrm{mg} / \mathrm{mL}$, respectively.

\section{Discussion}

The involvement of oxidative stress (OS) in neurodegenerative diseases, diabetes, cardiovascular diseases, ageing, and cancer is well documented [36, 37]. Natural antioxidants from plant materials may provide protection against $O S$ by inhibiting free radicals [38]. Therefore, in this study, the antioxidant and anticancer efficacies of $A$. graveolens, a known ayurvedic medicine used in traditional medicine system, were studied. The antioxidant activity is a composite process generally happening via various mechanisms and is affected by many other reasons that cannot be completely distinct by a single method. Therefore, it is necessary to measure by more than one type of assays, to take into elucidation of different mechanisms of antioxidant efficacies [33, 39-41]. Taking into account, in this study, four corresponding assays were performed to assess the antioxidant efficacies of AGME. Total antioxidant, DPPH, $\mathrm{H}_{2} \mathrm{O}_{2}$ scavenging, and ferrous reducing antioxidative capacity assays were achieved. The methods used in this study have different mechanism of reaction. Total antioxidant efficacy and DPPH assays are based on both single-electron transfer that produced violet solution [42] and hydrogen atom transfer reaction [43]. $\mathrm{OH}^{-}$is one of the most reactive free radicals; thus, it is required to deliberate the $\mathrm{H}_{2} \mathrm{O}_{2}$ scavenging activity of natural antioxidants. It can be generated by Fenton reaction between $\mathrm{H}_{2} \mathrm{O}_{2}$ and ferrous ion [44]. However, the mechanism of ferrous reducing antioxidative capacity is based on electron transfer [43]. All these assays significantly revealed the antioxidant and antiradical potential of AG-ME. Our results showed that the AG-ME possess significant total antioxidant capacity corresponding to $85.6 \%$ as compared to ascorbic acid (98.6\%) at highest concentration, i.e., $1000 \mu \mathrm{g} / \mathrm{ml}$. These data suggest the potential equivalent antioxidant ingredients of AG-ME since ascorbic acid is used as a reference standard to compare the potential antioxidant efficacy of AG-ME [45]. With increasing concentrations of AG-ME, there was an increase also found in DPPH activity with $\mathrm{IC}_{50}$ value of $225 \mu \mathrm{g} / \mathrm{ml}$. This indicates an increased ability of AG-ME to donate hydrogen ions ensuing in a brighter solution, which is relative to the number of gained electrons [46]. Thus, it may be suggested that AG-ME has potential DPPH activity by reducing the radicals to equivalent hydrazine as a result of its hydrogen ion donating ability. These results are in agreement with [47], who has reported that A. graveolens showed radical scavenging activity. The hydrogen peroxide scavenging capacity of AG-ME was also evaluated. As shown in Figure 2(a), a dose dependent radical scavenging potential of AG-ME was examined with the $\mathrm{IC}_{50}$ of $126.3 \mu \mathrm{g} / \mathrm{ml}$ compared to ascorbic acid $(100.5 \mu \mathrm{g} / \mathrm{ml})$. The abnormal gathering of hydrogen peroxide is accountable for OS which are associated with many chronic diseases [48, 49]. Consequently, regulation of $\mathrm{H}_{2} \mathrm{O}_{2}$ production by plant antioxidants is of high interest in biological research [50]. The ferrous reducing antioxidative capacity measures the reducing capacity of an antioxidant and its properties that are related to presence of compounds which exert their action by breaking free radical chain via donating a hydrogen atom [51]. As shown in Figure 2(b), the absorbance of AG$\mathrm{ME}$ was increased with the increasing concentrations because of formation of $\mathrm{Fe}^{++}$complex, as it was also observed in ascorbic acid. As observed in this investigation, the ferrous reducing activity of $\mathrm{AG}-\mathrm{ME}$ might be due to the hydrogen donating by AG-ME, which is accountable for its reducing capacity [52]. All these antioxidant assays clearly exhibited strong antioxidant activities, but slightly lesser than standard ascorbic acid. These results are accordance to other reports exhibiting antioxidant activity of $A$. graveolens essential oil and extracts because of the existence of the hydroxyl group, which are liable for antioxidant efficacies [16, 21, 22]. We have further evaluated the anticancer efficacies of AG-ME against MCF-7, A-549, and HeLa cell lines. The findings of MTT and NRU assays clearly showed that AG-ME significantly inhibited MCF-7, A-549, and HeLa cell viability with the increasing doses. There are various methods available for measuring the cytotoxicity of materials under in vitro condition [53]. In this study, we used 3-(4,5-dimethylthiozol-2-yl)-2,5-diphenyltetrazolium bromide salt assay (MTT) and neutral red uptake (NRU) assays, since they are wellknown and widely used methods for cytotoxic/antiproliferative efficacies of plant extracts. These assays are based on colorimetric measurements of viable cells after incubation with test materials. The MTT assay measures the functional state of mitochondria which indicate cell viability [54], and NRU assay is based on incorporation of NR dye into lysosomes of viable cells [55]. The AG-ME was found to inhibit MCF-7, A-549, and HeLa cells by $90 \%, 79 \%$, and $81 \%$, 


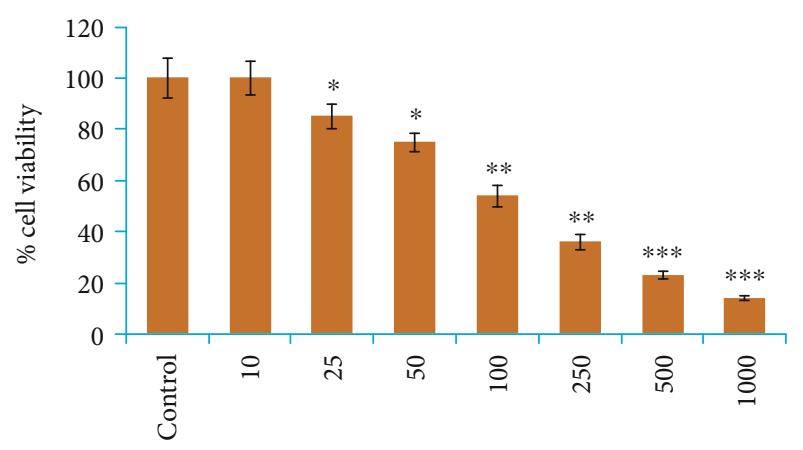

Concentrations $(\mu \mathrm{g} / \mathrm{ml})$

(a)

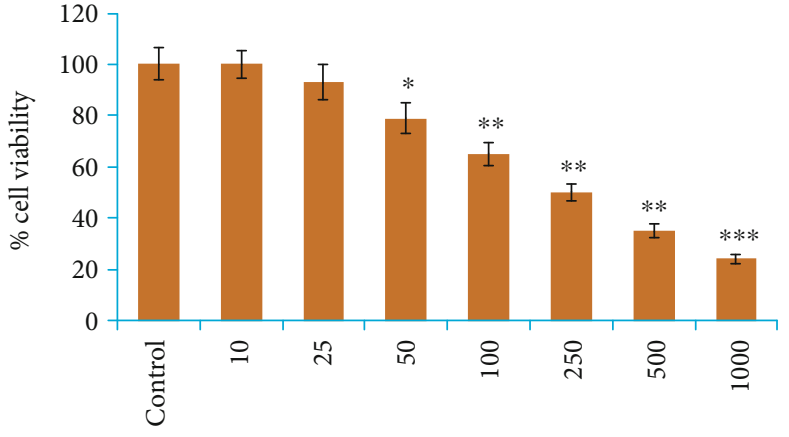

Concentrations $(\mu \mathrm{g} / \mathrm{ml})$

(b)

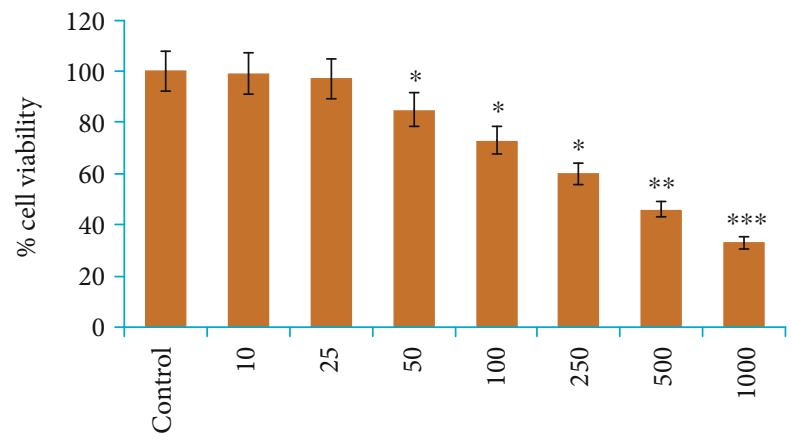

Concentrations $(\mu \mathrm{g} / \mathrm{ml})$

(c)

Figure 4: Cytotoxic potential of AG-ME against three different cancer cell lines exposed for $24 \mathrm{~h}$ at $10-1000 \mu \mathrm{g} / \mathrm{ml}$ concentrations measured by neutral red uptake (NRU) assay: (a) MCF-7 cells, (b) A-549 cells, and (c) HeLa cells. Results are expressed as the mean \pm S.D. of three different experiments. ${ }^{*} p<0.05,{ }^{* *} p<0.01$, and ${ }^{* * *} p<0.001$ vs. the control.
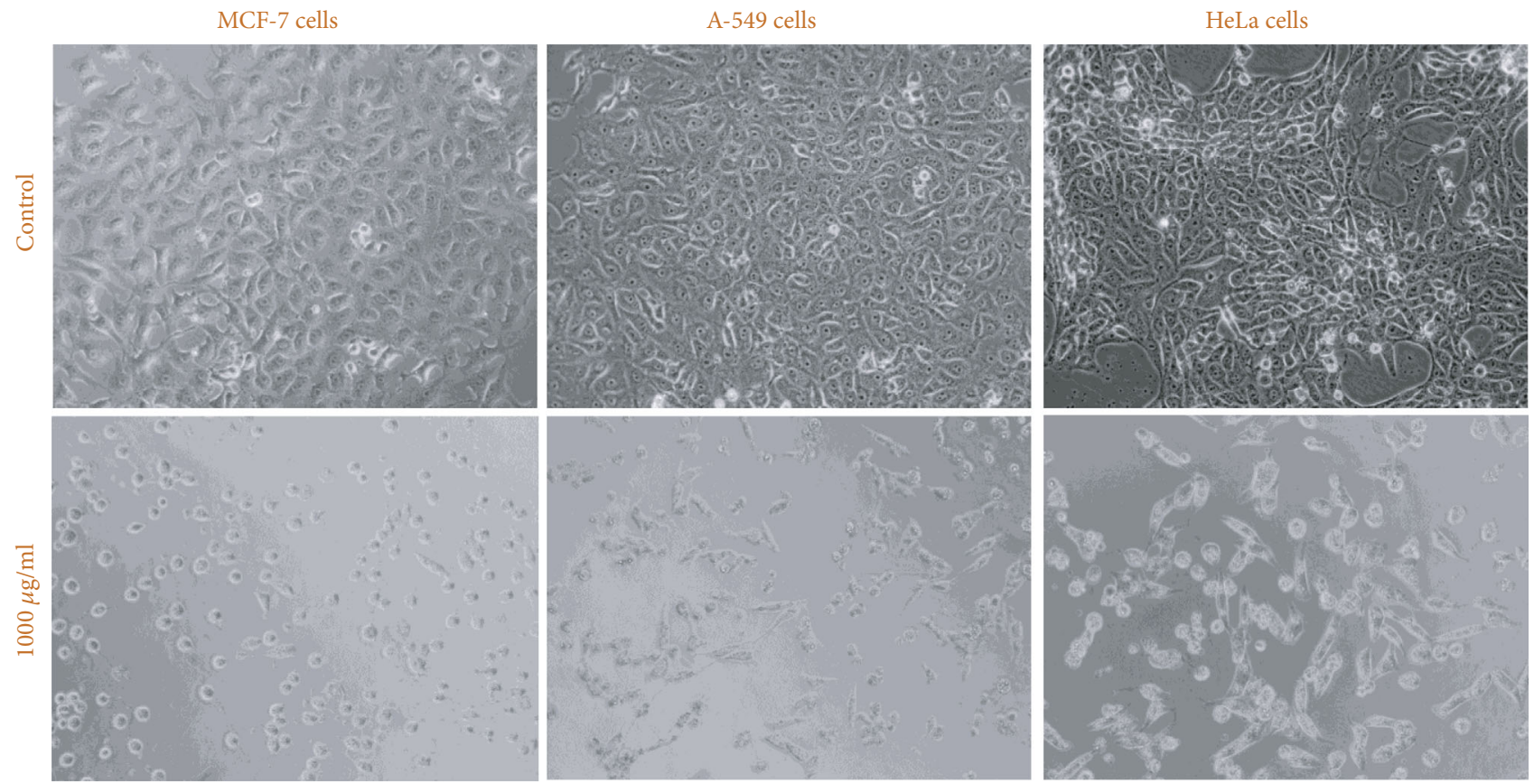

Figure 5: Morphological analysis of cytotoxicity of AG-ME for MCF-7, A-549, and HeLa cell lines exposed for $24 \mathrm{~h}$ at $1000 \mu \mathrm{g} / \mathrm{ml}$ concentration. Images were grabbed at 20x magnification power using phase contrast microscope (Olympus, CKX41, Japan). 


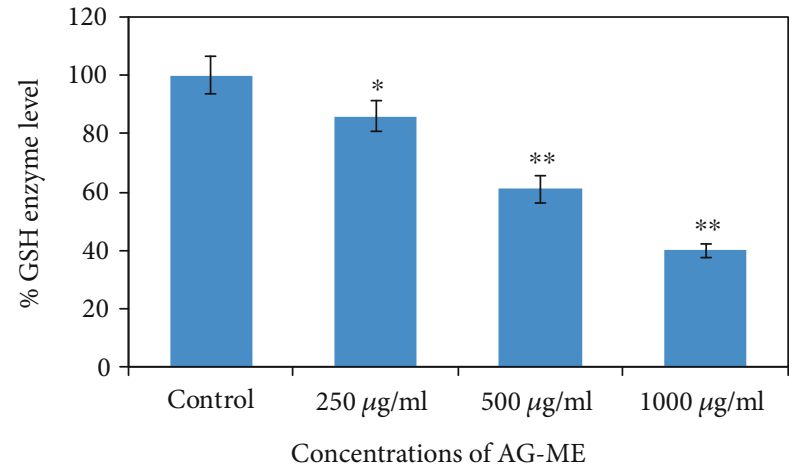

(a)
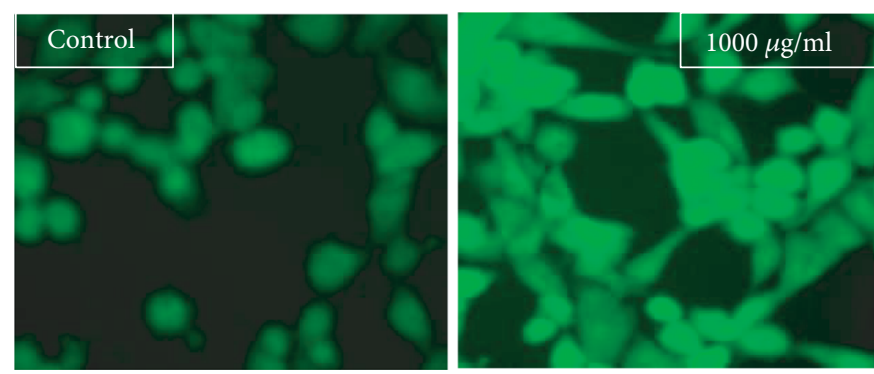

(c)

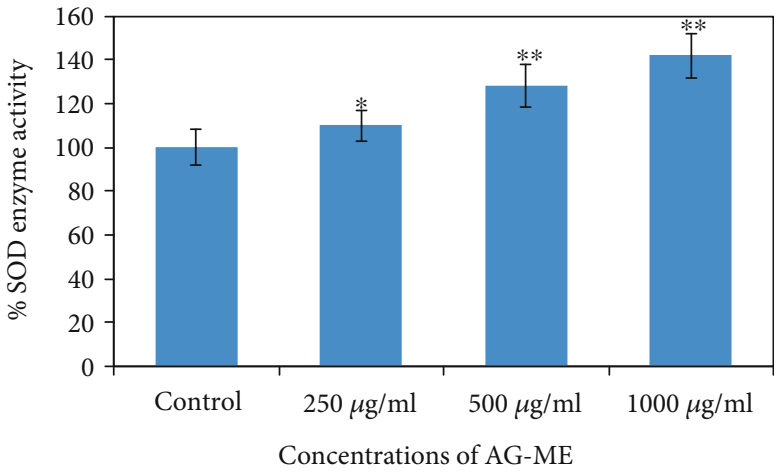

(b)

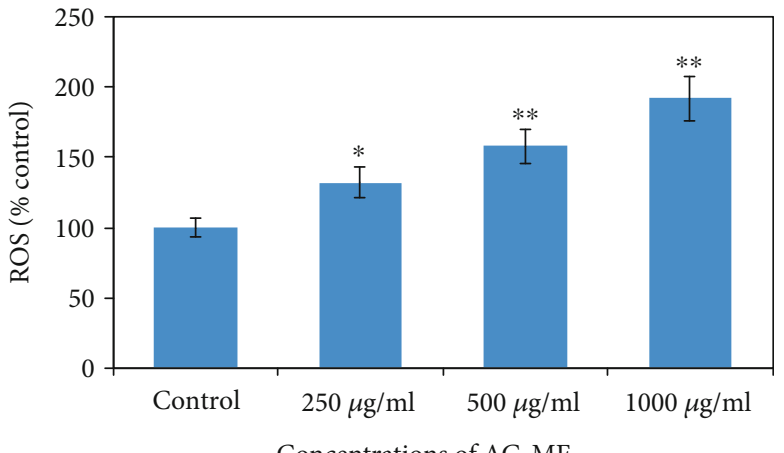

(d)

FIGURE 6: Oxidative stress measurements by (a) GSH enzyme activity and (b) SOD enzyme activity. (c) Representative fluorescence images showing ROS production in control and $1000 \mu \mathrm{g} / \mathrm{ml}$ of AG-ME. (d) Quantification of ROS production in MCF-7 cells treated with AG-ME at $250-1000 \mu \mathrm{g} / \mathrm{ml} .{ }^{*} p<0.05$ and ${ }^{* *} p<0.01$ vs. the control.

respectively, at $1000 \mu \mathrm{g} / \mathrm{ml}$ of AG-ME by MTT assay and $86 \%, 79 \%$, and $71 \%$, respectively, by NRU assay. The MCF7 cells were found to be more sensitive towards AG-ME followed by A-459 and HeLa cells. The $\mathrm{IC}_{50}$ values obtained for MCF-7, A-549, and HeLa cells were $104 \mu \mathrm{g} / \mathrm{ml}, 122$ $\mu \mathrm{g} / \mathrm{ml}$, and $156 \mu \mathrm{g} / \mathrm{ml}$, respectively, by MTT assay and $109 \mu \mathrm{g} / \mathrm{ml}, 250 \mu \mathrm{g} / \mathrm{ml}$, and $312 \mu \mathrm{g} / \mathrm{ml}$, respectively, by NRU assay. The cytotoxic activity of AG-ME was also validated by changes observed in the cellular morphology. The MCF7, A-549, and HeLa cells exposed to AG-ME at $1000 \mu \mathrm{g} / \mathrm{ml}$ lost their original shape, become less in number, rounded, and shrunken with apoptotic bodies. These results are corresponding to other reports which exhibited cytotoxic/ inhibitory activities of $A$. graveolens essential oil on MCF-7, $\mathrm{HeLa}$, and Caco-2 cell lines with $\mathrm{IC}_{50}$ values of $67 \mu \mathrm{g} / \mathrm{ml}$, $93 \mu \mathrm{g} / \mathrm{ml}$, and $216 \mu \mathrm{g} / \mathrm{ml}$, respectively, as measured by MTT assay [56]. In another study, it has also been demonstrated that the essential oil of $A$. graveolens revealed a dosedependent anticancer/antiproliferative activity against human hepatocellular carcinoma cells with $\mathrm{IC}_{50}$ of $59.6 \mu \mathrm{g} / \mathrm{ml}$ [20]. The methanolic extract of $A$. graveolens has also been reported to exhibit cytotoxic/anticancer activities against mouse leukemia L1210 cells [57]. Further to explore the mechanism(s) of cytotoxicity induced by AG-ME, we have selected most sensitive cell line, MCF-7. Herein, we explored the effects of AG-ME on the GSH and SOD activities in MCF-7 cells treated with $250-1000 \mu \mathrm{g} / \mathrm{ml}$ of AG-ME for $24 \mathrm{~h}$. GSH and SOD are known to play a significant role in maintaining cellular redox balance or oxidative stress through its antioxidant mechanism. Our results showed that the GSH activity was decreased and SOD activity was increased with the increasing concentrations of AG-ME. These results are accordance to the previously published reports suggesting that the exposure of plant extracts could decrease the GSH [58] and increase the SOD activities [59] in MCF-7 (human breast carcinoma). The lowering of GSH activity and an increase in SOD activity indicated that oxidative stress is involved in MCF-7 cell death-induced by AG-ME. Oxidative stress tempted by the accumulation of ROS increases the sensitivity of cancer cells and is capable of inducing apoptotic cell death [60]. Based on the results obtained by DCF-DA assay, AG-ME was found to increase ROS production in MCF-7 cells, suggested that AG-ME induced oxidative stress by ROS generation. Excessive ROS generation is known to cause damage to cellular DNA, lipids, proteins, and biomembranes which leads to cell death [61]. Studies showed that excessive ROS generation can facilitate mitochondrial permeabilization [62]. The decrease of MMP level is one of the early biochemical markers of apoptosis progression. The findings of the study also displayed that AG-ME significantly decreased MMP level in MCF-7 cells. These findings provided a strong evidence towards the role of ROS mediated loss of MMP in MCF-7 cell death. To further elucidate the pathways of cell 

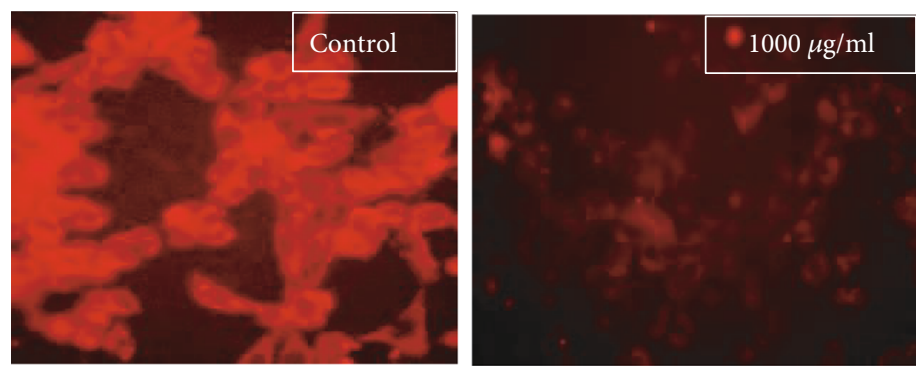

(a)

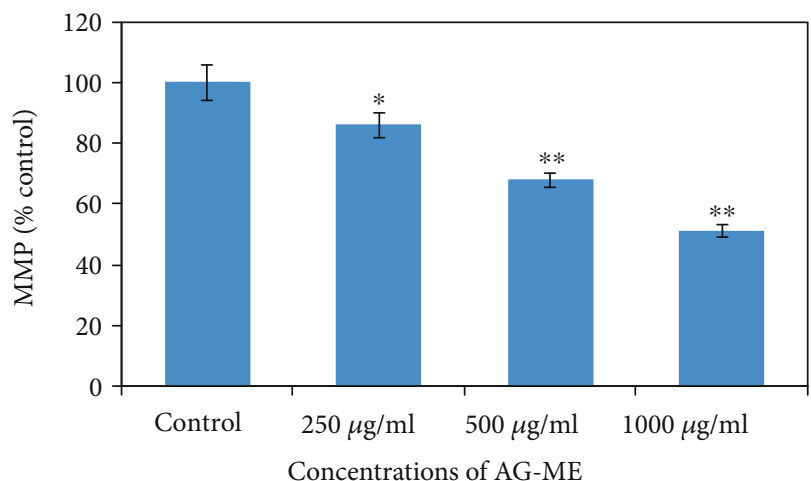

(b)

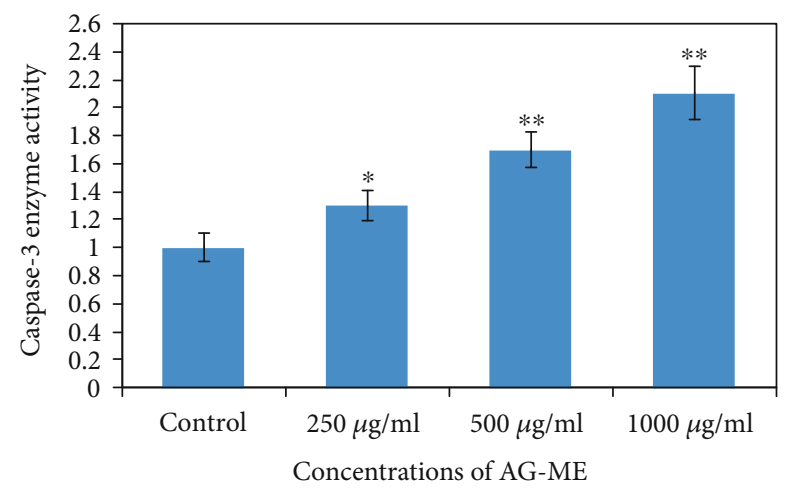

(c)

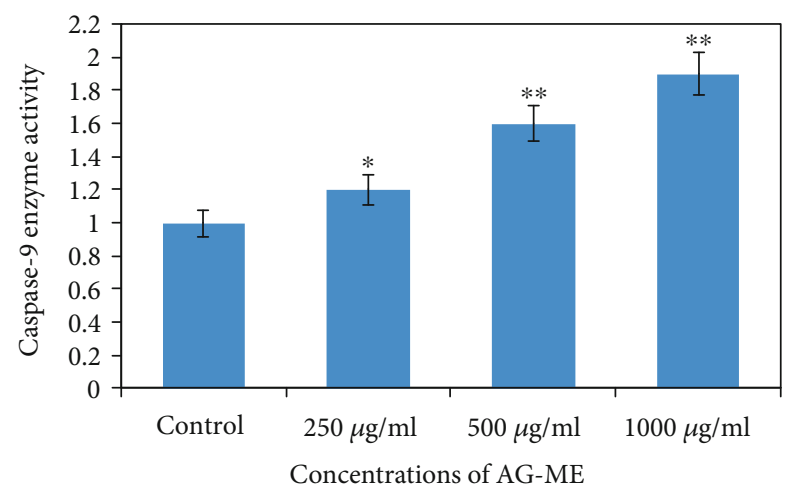

(d)

Figure 7: AG-ME induced loss of MMP and caspase enzyme activities in MCF-7 cells. (a) Representative images showing MMP level by Rh-123 probe in control and $1000 \mu \mathrm{g} / \mathrm{ml}$ of AG-ME. (b) Quantification of intensity of Rh-123 dye in MCF-7 cells treated with AG-ME at $250-1000 \mu \mathrm{g} / \mathrm{ml}$. (c) Caspase-3 and (d) caspase-9 enzyme activities. ${ }^{*} p<0.05$ and ${ }^{* *} p<0.01$ vs. the control.

death induced by AG-ME, caspase- 3 and caspase- 9 enzyme activities were evaluated. Caspase- 3 is one of the caspases involved in the final implementation of dying cells whereas caspase- 9 is an initiator involved in the intrinsic pathway [63]. Thus, to understand the mechanisms of action induced by AG-ME, caspase- 3 and caspase- 9 enzyme activities were measured. The results exhibited that AG-ME induced a dose-dependent increase in caspase- 3 and caspase- 9 activities in MCF-7 cells. These results suggest that the AG-MEinduced MCF-7 cell death is caspase-dependent. The caspase-dependent anticancer activity of plant extract has also been previously reported in MCF-7 [64]. A large number of phytoconstituents present in methanolic extracts of A. graveolens have already been reported [65]; therefore, we assume that the anticancer efficacies of AG-ME observed in present investigation might be due to the existence of phytocompounds in it. Herein, the reported results also supported the relationship of cytotoxicity with antioxidant activities. Consequently, the antioxidant activities of AG-ME might contribute to its cytotoxicity/anticancer activities.

\section{Conclusion}

The present study provided a reasoning and reassurance for the uses of $A$. graveolens for medical purposes. The methanolic extract of $A$. graveolens (AG-ME) showed significant antioxidant efficacies as observed by total antioxidant, DPPH radical scavenging, $\mathrm{H}_{2} \mathrm{O}_{2}$, and ferrous reducing capacities. As it can be seen from this investigation, A. graveolens may be used as a good supply of natural antioxidants through probable nutrition supplement. AG-ME also showed a 
dose-dependent strong anticancer/cytotoxic potential against MCF-7, A-549, and HeLa cell lines. It further exhibited oxidative stress-mediated ROS production and loss of MMP in MCF-7 cells. A dose-dependent increase in the activities of caspase- 3 and caspase- 9 suggests that the AG-ME-induced MCF-7 cell death is caspase-dependent. Additional investigation is required to examine biological and anticancer activities under in vivo system to discover possible beneficial use of AG-ME against diseases.

\section{Data Availability}

The data used to support the findings of this study are included within the article.

\section{Conflicts of Interest}

The authors declare that they have no conflicts of interest.

\section{Acknowledgments}

This research project was supported by a grant from the "Research Centre of the Female Scientific and Medical Colleges", Deanship of Scientific Research, King Saud University.

\section{References}

[1] V. Lobo, A. Patil, A. Phatak, and N. Chandra, "Free radicals, antioxidants and functional foods: impact on human health," Pharmacognosy Reviews, vol. 4, no. 8, pp. 118-126, 2010.

[2] A. Phaniendra, D. B. Jestadi, and L. Periyasamy, "Free radicals: properties, sources, targets, and their implication in various diseases," Indian Journal of Clinical Biochemistry, vol. 30, no. 1, pp. 11-26, 2015.

[3] B. Halliwell and J. M. C. Gutteridge, "Free radicals in biology and medicine," Journal of Free Radicals in Biology \& Medicine, vol. 1, no. 4, pp. 331-332, 1985.

[4] E. B. Kurutas, "The importance of antioxidants which play the role in cellular response against oxidative/nitrosative stress: current state," Nutrition Journal, vol. 15, no. 1, pp. 1-22, 2015.

[5] K. G. Ramawat and J. M. Merillon, Bioactive Molecules and Medicinal Plants, Springer, Berlin Heidelberg, New York, 2008.

[6] A. Rebaya, S. Belghith, B. Baghdikian et al., "Total phenolic, total flavonoid, tannin content, and antioxidant capacity of Halimiumhalimifolium (Cistaceae)," Journal of Applied Pharmaceutical Science, vol. 5, pp. 52-57, 2015.

[7] J. Sun, Y. F. Chu, X. Wu, and R. H. Liu, "Antioxidant and antiproliferative activities of common fruits," Journal of Agricultural and Food Chemistry, vol. 50, no. 25, pp. 7449-7454, 2002.

[8] R. H. Liu, "Health benefits of ruit and vegetables are from additive and synergistic combinations of phytochemicals," The American Journal of Clinical Nutrition, vol. 78, pp. 517-520, 2003.

[9] M. M. Ramadan, N. N. Abd-Algader, H. H. El-kamali, K. Z. Ghanem, and A. H. Farrag, "Volatile compounds and antioxidant activity of the aromatic herb Anethum graveolens," J. Arab Soc. Med. Res., vol. 8, no. 2, pp. 79-88, 2013.

[10] R. M. Perez Gutierrez and Y. T. Gallardo Navarro, "Antioxidant and hepatoprotective effects of the methanol extract of the leaves of Satureja macrostema," Pharmacognosy Magazine, vol. 6, no. 22, pp. 125-131, 2010.

[11] Y. Kumar and V. Kumar, "Comparative antioxidant capacity of plant leaves and herbs with their antioxidative potential in meat system under accelerated oxidation conditions," J. Food Meas Charact., vol. 14, no. 6, pp. 3250-3262, 2020.

[12] Y. J. Zhang, R. Y. Gan, S. Li et al., "Antioxidant phytochemicals for the prevention and treatment of chronic diseases," Molecules, vol. 20, no. 12, pp. 21138-21156, 2015.

[13] C. I. Ukaegbu, S. R. Shah, H. A. Hamid, Z. Normaiza, and O. R. Alara, "Extracts of Hypsizygus tessellatus (white var.) caps inhibited MCF-7 and MDA-MB-231 cell lines proliferation," J. Food Meas Charact, vol. 13, no. 1, pp. 368-382, 2019.

[14] P. C. Karmakar, R. Yesmin, H. Ali et al., "Antioxidant, cytotoxic and apoptotic potentials of seeds of Momordica subangulata subsp. renigera inhibit the growth of Ehrlich ascites carcinoma in mice," J. Food Meas Charact, vol. 13, no. 4, pp. 3049-3059, 2019.

[15] S. Jana and G. S. Shekhawat, "Anethum graveolens: an Indian traditional medicinal herb and spice," Pharmacognosy Reviews, vol. 4, no. 8, pp. 179-184, 2010.

[16] N. Kaur, K. K. Chahal, A. Kumar, R. Singh, and U. Bhardwaj, "Antioxidant activity of Anethum graveolens L. essential oil constituents and their chemical analogues," Journal of Food Biochemistry, vol. 43, no. 4, article e12782, 2019.

[17] M. Naseri, F. Mojab, M. Khodadoost et al., "The study of antiinflammatory activity of oil-based dill (Anethum graveolens L.) extract used topically in formalin-induced inflammation male rat paw," Iran. J. Pharm. Res, vol. 11, no. 4, pp. 1169$1174,2012$.

[18] M. T. Goodarzi, I. Khodadadi, H. Tavilani, and E. Abbasi Oshaghi, "The Role of Anethum graveolens L. (Dill) in the Management of Diabetes," Journal of Tropical Medicine, vol. 2016, Article ID 1098916, 11 pages, 2016.

[19] K. Karimi, M. Arzanlou, and I. Pertot, "Antifungal activity of the dill (Anethum graveolensL.) seed essential oil against strawberry anthracnose underin vitroandin vivoconditions," Arch Phytopathol Pflanzenschutz, vol. 49, no. 19-20, pp. 554566, 2016.

[20] E. S. Al-Sheddi, N. A. Al-Zaid, M. M. Al-Oqail, S. M. AlMassarani, A. A. El-Gamal, and N. N. Farshori, "Evaluation of cytotoxicity, cell cycle arrest and apoptosis induced by _Anethum graveolens_ L _._. essential oil in human hepatocellular carcinoma cell line," Saudi Pharm. J, vol. 27, no. 7, pp. 1053-1060, 2019.

[21] Y. S. Shyu, J. T. Lin, Y. T. Chang, C. J. Chiang, and D. J. Yang, "Evaluation of antioxidant ability of ethanolic extract from dill (Anethum graveolens L.) flower," Food Chemistry, vol. 115, no. 2, pp. 515-521, 2009.

[22] S. Selen Isbilir and A. Sagiroglu, "Antioxidant potential of different dill (Anethum GraveolensL.) leaf extracts," International Journal of Food Properties, vol. 14, no. 4, pp. 894-902, 2011.

[23] J. S. Bertram, “The molecular biology of cancer," Molecular Aspects of Medicine, vol. 21, no. 6, pp. 167-223, 2000.

[24] S. M. Chan, K. S. Khoo, and N. W. Sit, "Interactions between plant extracts and cell viability indicators during cytotoxicity testing: implications for ethnopharmacological studies," Tropical Journal of Pharmaceutical Research, vol. 14, no. 11, pp. 1991-1998, 2015. 
[25] K. Muniyandi, E. George, V. Mudili et al., "Antioxidant and anticancer activities of Plectranthus stocksii Hook. f. leaf and stem extracts," Agric. Nat. Resour, vol. 51, no. 2, pp. 63-73, 2017.

[26] B. Buranrat, S. Boontha, P. Temkitthawon, and P. Chomchalao, "Anticancer activities of Careya arborea Roxb on MCF-7 human breast cancer cells," Biologia, vol. 75, no. 12, pp. 2359-2366, 2020.

[27] T. P. Devasagayam and K. B. Sainis, "Immune system and antioxidants, especially those derived from Indian medicinal plants," Indian Journal of Experimental Biology, vol. 40, no. 6, pp. 639-655, 2002.

[28] P. P. Kedari and N. P. Malpathak, "Screening of Chonemorpha fragrans bioactive extracts for cytotoxicity potential and inhibition studies of key enzymes involved in replication," Pharmacognosy Magazine, vol. 12, Suppl 3, pp. S297-S302, 2016.

[29] S. C. Ghagane, S. I. Puranik, R. B. Nerli, and M. B. Hiremath, "Evaluation of in vitro antioxidant and anticancer activity of Allophylus cobbe leaf extracts on DU-145 and PC-3 human prostate cancer cell lines," Cytotechnology, vol. 69, no. 1, pp. 167-177, 2017.

[30] M. A. Khan, A. A. Rahman, S. Islam et al., "A comparative study on the antioxidant activity of methanolic extracts from different parts of Morus alba L. (Moraceae)," BMC Research Notes, vol. 6, no. 1, p. 24, 2013.

[31] M. S. Blois, "Antioxidant determinations by the use of a stable free radical," Nature, vol. 181, no. 4617, pp. 1199-1200, 1958.

[32] B. Bozin, N. Mimica-Dukic, I. Samojlik, A. Goran, and R. Igic, "Phenolics as antioxidants in garlic (Allium sativum L., Alliaceae)," Food Chemistry, vol. 111, no. 4, pp. 925-929, 2008.

[33] M. El Jemli, R. Kamal, I. Marmouzi, A. Zerrouki, Y. Cherrah, and K. Alaoui, "Radical-scavenging activity and ferric reducing ability of Juniperus thurifera (L.), J. oxycedrus (L.), J. phoenicea (L.) and Tetraclinis articulata (L.)," Advances in Pharmacological Sciences, vol. 2016, Article ID 6392656, 6 pages, 2016.

[34] S. Botcha and S. D. Prattipati, "Green synthesis of silver nanoparticles using Hyptis suaveolens (L.) Poit leaf extracts, their characterization and cytotoxicity evaluation against PC-3 and MDA-MB 231 cells," Biologia, vol. 74, no. 7, pp. 783-793, 2019.

[35] E. S. Al-Sheddi, N. N. Farshori, M. M. Al-Oqail et al., "Cytotoxicity and mitochondrial-mediated apoptosis induced by fenugreek seed oil in human hepatocellular carcinoma cells via reactive oxygen species generation," Pharmacognosy Magazine, vol. 15, no. 60, pp. 12-17, 2019.

[36] B. M. Hybertson, B. Gao, S. K. Bose, and J. M. McCord, "Oxidative stress in health and disease: the therapeutic potential of Nrf2 activation," Molecular Aspects of Medicine, vol. 32, no. 46, pp. 234-246, 2011.

[37] A. Rahal, A. Kumar, V. Singh et al., "Oxidative stress, prooxidants, and antioxidants: the interplay," BioMed Research International, vol. 2014, Article ID 761264, 19 pages, 2014.

[38] J. Dai and R. J. Mumper, "Plant phenolics: extraction, analysis and their antioxidant and anticancer properties," Molecules, vol. 15, no. 10, pp. 7313-7352, 2010.

[39] K. Schlesier, M. Harwat, V. Böhm, and R. Bitsch, "Assessment of antioxidant activity by using different in vitro methods," Free Radical Research, vol. 36, no. 2, pp. 177-187, 2002.

[40] S. P. Wong, L. P. Leong, and J. H. Koh, "Antioxidant activities of aqueous extracts of selected plants," Food Chemistry, vol. 99, no. 4, pp. 775-783, 2006.
[41] M. S. Sopee, A. Azlan, and H. E. Khoo, "Comparison of antioxidants content and activity of Nephelium mutabile rind extracted using ethanol and water," J. Food Meas Charact., vol. 13, no. 3, pp. 1958-1963, 2019.

[42] S. Chekuri, B. Arunjyothi, and R. R. Anupalli, "Radical scavenging activity (2, 2-diphenyl-1-picrylhydrazyl) of acalypha indica linn. (Euphorbeace family)," International Journal of Pharmaceutical Sciences and Research, vol. 9, no. 1, pp. 313$317,2018$.

[43] R. L. Prior, X. Wu, and K. Schaich, "Standardized methods for the determination of antioxidant capacity and phenolics in foods and dietary supplements," Journal of Agricultural and Food Chemistry, vol. 53, no. 10, pp. 4290-4302, 2005.

[44] J. Treml and K. Šmejkal, "Flavonoids as potent scavengers of hydroxyl radicals," Comprehensive Reviews in Food Science and Food Safety, vol. 15, no. 4, pp. 720-738, 2016.

[45] A. B. Aliyu, M. A. Ibrahim, A. M. Musa, A. O. Musa, J. J. Kiplimo, and A. O. Oyewale, "Free radical scavenging and total antioxidant capacity of root extracts of Anchomanes difformis Engl.(Araceae)," Acta Poloniae Pharmaceutica, vol. 70, no. 1, pp. 115-121, 2013.

[46] O. E. Adebiyi, F. O. Olayemi, T. Ning-Hua, and Z. Guang-Zhi, "In vitro antioxidant activity, total phenolic and flavonoid contents of ethanol extract of stem and leaf of Grewia carpinifolia," Beni-Suef Univ. J. Basic Appl. Sci., vol. 6, no. 1, pp. 1014, 2017.

[47] E. A. Oshaghi, I. Khodadadi, H. Tavilani, and M. T. Goodarzi, "Aqueous extract of Anethum Graveolens L. has potential antioxidant and antiglycation effects," Iran. J. Med. Sci, vol. 41, no. 4, pp. 328-333, 2016.

[48] E. A. Mahmoud, J. Sankaranarayanan, J. M. Morachis, G. Kim, and A. Almutairi, "Inflammation responsive logic gate nanoparticles for the delivery of proteins," Bioconjugate Chemistry, vol. 22, no. 7, pp. 1416-1421, 2011.

[49] C. de Gracia Lux, S. Joshi-Barr, T. Nguyen et al., "Biocompatible polymeric nanoparticles degrade and release cargo in response to biologically relevant levels of hydrogen peroxide," Journal of the American Chemical Society, vol. 134, no. 38, pp. 15758-15764, 2012.

[50] S. Aryal, M. K. Baniya, K. Danekhu, P. Kunwar, R. Gurung, and N. Koirala, "Total phenolic content, flavonoid content and antioxidant potential of wild vegetables from Western Nepal," Plants (Basel), vol. 8, no. 4, p. 96, 2019.

[51] P. D. Duh, P. C. Du, and G. C. Yen, "Action of methanolic extract of mung bean hulls as inhibitors of lipid peroxidation and non-lipid oxidative damage," Food and Chemical Toxicology, vol. 37, no. 11, pp. 1055-1061, 1999.

[52] S. Salmanian, A. Sadeghi Mahoonak, M. Alami, and M. Ghorbani, "Phenolic content, antiradical, antioxidant, and antibacterial properties of hawthorn (Crataegus elbursensis) seed and pulp extract," Journal of Agricultural Science and Technology, vol. 16, pp. 343-354, 2014.

[53] O. S. Aslantürk, "In vitro cytotoxicity and cell viability assays: principles, advantages, and disadvantages," in Genotoxicity- $a$ Predictable Risk to Our Actual World, M. L. Larramendy and S. Soloneski, Eds., vol. 2018, pp. 1-16, InTech, 2018.

[54] J. M. Edmondson, L. S. Armstrong, and A. O. Martinez, "A rapid and simple MTT-based spectrophotometric assay for determining drug sensitivity in monolayer cultures," Journal of Tissue Culture Methods, vol. 11, no. 1, pp. 15-17, 1988. 
[55] E. Borenfreund and J. A. Puerner, “A simple quantitative procedure using monolayer cultures for cytotoxicity assays (HTD/NR-90)," Journal of Tissue Culture Methods, vol. 9, no. 1, pp. 7-9, 1985.

[56] F. S. Sharopov, M. Wink, I. S. Gulmurodov, S. J. Isupov, H. Zhang, and W. N. Setzer, "Composition and bioactivity of the essential oil of Anethum graveolens L. from Tajikistan," Int. J. Med. Arom. Plants, vol. 3, no. 2, pp. 125-130, 2013.

[57] E. A. Goun, V. M. Petrichenko, S. U. Solodnikov et al., "Anticancer and antithrombin activity of Russian plants," Journal of Ethnopharmacology, vol. 81, no. 3, pp. 337-342, 2002.

[58] F. Ou-Yang, I. Tsai, J. Y. Tang et al., "Antiproliferation for breast cancer cells by ethyl acetate extract of Nepenthes thorellii x (ventricosa x maxima)," International Journal of Molecular Sciences, vol. 20, no. 13, p. 3238, 2019.

[59] N. N. Abrahim, M. S. Kanthimathi, and A. Abdul-Aziz, "Piper betle shows antioxidant activities, inhibits MCF-7 cell proliferation and increases activities of catalase and superoxide dismutase," BMC Complementary and Alternative Medicine, vol. 12, no. 1, p. 220, 2012.

[60] J. Wen, K. R. You, S. Y. Lee, C. H. Song, and D. G. Kim, “Oxidative stress-mediated apoptosis," The Journal of Biological Chemistry, vol. 277, no. 41, pp. 38954-38964, 2002.

[61] M. Redza-Dutordoir and D. A. Averill-Bates, "Activation of apoptosis signalling pathways by reactive oxygen species," Biochimica et Biophysica Acta, Molecular Cell Research, vol. 1863, no. 12, pp. 2977-2992, 2016.

[62] G. Kroemer and J. C. Reed, "Mitochondrial control of cell death," Nature Medicine, vol. 6, no. 5, pp. 513-519, 2000.

[63] J. A. Badmus, O. E. Ekpo, A. A. Hussein, M. Meyer, and D. C. Hiss, "Antiproliferative and Apoptosis Induction Potential of the Methanolic Leaf Extract of Holarrhena floribunda (G. Don)," Altern. Med, vol. 2015, article 756482, pp. 1-11, 2015.

[64] N. G. Panicker, S. O. M. S. Balhamar, S. Akhlaq et al., "Organic extracts from Cleome droserifolia exhibit effective caspasedependent anticancer activity," BMC Complement. Med. Ther., vol. 20, no. 1, p. 74, 2020.

[65] T. Ishikawa, M. Kudo, and J. Kitajima, "Water-soluble constituents of dill," Chemical \& Pharmaceutical Bulletin, vol. 50, no. 4 , pp. 501-507, 2002. 